\title{
The American Public and the Room to Maneuver: Responsibility Attributions and Policy Efficacy in an Era of Globalization
}

\author{
Timothy Hellwig \\ University of Houston \\ thellwig@uh.edu
}

\author{
Eve Ringsmuth \\ University of Minnesota \\ ringsmuth@umn.edu
}

\author{
John R. Freeman \\ University of Minnesota \\ freeman@umn.edu
}

\section{First Draft: Comments welcome. Please cite but do not quote without authors permission.}

\begin{abstract}
Despite the increasing integration of world markets, most political scientists contend that governments retain much policy "room to maneuver." Moreover, citizens presumably agree to increased trade and direct foreign investment because they believe their governments can cushion the impacts of market forces. In this sense, economic globalization is compatible with democracy. Rarely, however, are data provided that demonstrate citizens appreciation for the room to maneuver, let alone their positive evaluation of it.

This paper reports results of the first study of American's attitudes about the room to maneuver. Employing data from an original experiment of randomly sampled adults, we address three questions. First, who do citizens identify as most responsible for the performance of the U.S. economy, elected officials or market forces? Second, how do individual attributes affect how citizens reason about the room to maneuver? And third, what is the relationship between judgments about the room to maneuver and satisfaction with democracy?

We show that while a majority of Americans believe their governments retain the room to maneuver, there exists a substantial minority-mostly Republican identifiers and more educated citizens-which does not. Both this minority and the believers in room to maneuver majority are satisfied with democracy - seemingly because Republican partisans and the more educated see the room to maneuver as undesirable; they prefer less government, the kind of government that the Bush Administration presumably represents. Finally, as regards question wording effects, the results are mixed. On the one hand, contra other studies on globalization and public attitudes, we find no evidence of priming effects. However, attributions are shaped by the response set: when given an item attributing economic performance to national or international business cycles, a plurality of respondents attribute responsibility for national economic conditions to market forces rather than to elected officials. These findings require us to reconsider current thinking in international and comparative political economy on connections between market liberalization, policy efficacy, and democratic accountability.
\end{abstract}

Paper prepared for delivery at the Annual Meeting of the Midwest Political Science Association, April 12-15, 2007. We thank James Druckman, Diana Mutz, Thomas Rudolph, the staff of the Indiana Survey Research Center, and anonymous reviewers for advice on this project. Data collected by TESS, NSF Grant 0094964, Diana C. Mutz and Arthur Lupia Investigators. The authors of the paper alone are responsible for its contents. 


\section{Introduction}

Most political economists today agree that, despite the increasing integration of world markets, governments retain much "room to maneuver." According to this conventional wisdom, there remain major differences in monetary, tax, and spending policies and, concomitantly, significant differences across countries in prices, employment, and other macroeconomic outcomes (e.g., Bearce 2007; Iversen and Cusack 2000; Steinmo 2002; Franzese 2002; Mosley 2000; Iversen 1999; Garrett 1998). Some scholars explain the openness of advanced industrial economies in terms of this room to maneuver. Consistent with the logic of “embedded liberalism” (Ruggie 1982), citizens presumably agree to increased trade and direct foreign investment because they believe that through public policies their governments can cushion the impacts of international economic forces. In this sense, economic globalization is compatible with democracy.

However, most political economists assume the public's appreciation for the room to maneuver. Scholars assert citizens' understanding and positive evaluation of their government's capacity for managing economic outcomes. In fact, no micro-level evidence has been produced that demonstrate such appreciation and(or) reasoning on the part of the American public. In addition, studies of this subject in other economically open democracies yield disturbing results. Illustrative are the findings of a public opinion survey conducted in Britain in 2001. When asked, "In today's worldwide economy, how much influence do you think British governments have on the British economy?," almost half (43\%) answered either "not very much" or "hardly any." (Heath et al. 2002). A similar question asked in France in 1997 found that 53\% thought their government had either "not very much" or "very little" room to maneuver (CEVIPOF et al. 2001). These results are inconsistent with the conventional wisdom. They suggest that citizens 
are not aware of the policy and macroeconomic divergence scholars have found, that citizens do not attribute the performance of their economies to the policy choices of their elected officials, or both.

This paper provides the first analysis of citizen perceptions of the room to maneuver in the United States. Parting from the highly aggregated analyses of previous studies, we analyze data from an original survey experiment on this subject. We address three sets of questions. First, who do citizens identify as most responsible for the state of the American economy, domestic actors market forces? And do these responsibility attributions depend on question wording, particularly, priming about economic globalization? Second, do understandings of the room to maneuver affect (reflect) attitudes toward political parties? And third, do perceptions of no room to maneuver reduce levels of satisfaction with how democracy works in the United States?

We find that while a majority of Americans believe their governments retain the room to maneuver, there exists a substantial minority_mostly Republican identifiers and more educated citizens-which does not. Both this minority and the believers in room to maneuver majority are satisfied with democracy—seemingly because Republican partisans and the more educated see room to maneuver as undesirable. These individuals are skeptical of government intervention in the economy; they prefer less government, the kind of government that the Bush Administration presumably represents. Finally, as regards question wording effects, the results are mixed. Contra other studies on globalization and public attitudes, we find no evidence of priming effects. On the other hand, experimental treatments reveal that attributions are shaped by the response set: contra models of retrospective voting, when respondents are given an item attributing responsibility for economic performance to national or international business cycles, 
a plurality of respondents attribute responsibility for national economic conditions to market forces rather than to elected officials.

\section{The International Economy, Public Opinion, and Policy Responsibility}

This study is informed by research in two areas: research on the domestic political consequences of global markets and public opinion research on responsibility attributions and attitudes toward democracy. Regarding the former, the political consequences of open markets continues to be a central area of investigation among political economists. One argument is that globalization creates a "race-to-the-bottom" in the state's regulatory and spending powers, leaving elected officials with little policy flexibility. In a world where the rules increasingly are set by impersonal and unaccountable financial markets, the argument goes, states must compete with one another. To attract capital, national policies converge, characterized by spending cuts, lower taxes, and a general weakening of the state's productive and redistributive capacity (e.g., Clark 2003; Korpi and Palme 2003; Mishra 1999; Moses 2000; Strange 1996).

Despite the logic of this "globalization thesis," evidence from advanced capitalist societies concludes that the effects of market integration on politics are small in scope and limited in range. In place of economic globalization, scholars have identified several factors that allow governments to pursue distinct national policies. Some point to particular path-dependent trajectories which insulate states from global pressures (Pierson 2001). Others focus on how domestic institutions or welfare-production regimes diffuse global economic forces (Hall and Soskice 2001; Iversen 2005; Swank 2002), or combine with partisan politics to produce specific policy outcomes (Garrett 1998). Through adjustment assistance, investment in human capital, and other reforms, policymakers in developed welfare states still can take action to counter social 
dislocations associated with market integration. According to this revisionist perspective, the welfare consequences — and by implication, democratic consequences — of globalization are innocuous.

These two arguments have different implications for representation and popular sovereignty. The first view contends that globalization's policy constraints are severe, while the second finds the impact of globalization on public policy to be spurious or overblown. Neither perspective, however, considers how the international economy shapes public perceptions of the room to maneuver. A sense of the publics' perceptions, however, is essential for understanding how international markets matter for the health of mass politics. If citizens perceive the constraints imposed by economic globalization to be severe, their support for economic policies is hard to justify. If citizens believe that there is room to maneuver, their support for policies should be based on an understanding that it is the policies of their elected officials—and not forces beyond the control of their elected officials - that lead to particular macroeconomic outcomes (on these points see Hellwig and Samuels 2007; Sattler et al. 2007; Sattler et al forthcoming). While a growing number of studies on globalization have employed public opinion data, these works focus on narrower questions such as individual preferences for protectionism (Baker 2005; Hainmueller and Hiscox 2006; Hiscox 2006; Kaltenthaler et al. 2004; Mayda and Rodrik 2005) and feelings of worker insecurity (Kwon 2004; Mughan et al. 2003; Scheve and Slaughter 2004). This research provides useful insights about popular perceptions of globalization. But it does not address the issues that lie at the heart of the functioning of democracy, such as policy efficacy, democratic accountability, and popular sovereignty. ${ }^{1}$

\footnotetext{
${ }^{1}$ Telling is the fact that while motivated by globalization, some studies lack the necessary data to actually test the effects of (perceptions) of the world economy for mass political behavior (e.g., Kwon 2004; Mughan et al. 2003).
} 
Studies that bear more directly on these issues are found in the literature on economic voting and responsibility attributions. The most common argument is that voters retrospectively evaluate the state of the economy and then use this information to reward or punish the incumbent executive. While attractive both normatively and empirically, the associated model of economic voting has been challenged on several grounds. ${ }^{2}$ One body of work contends that individual attributes condition the effect of policy evaluations. Sources of heterogeneity across individuals include political sophistication, social class, political interest, and partisan attachments (Duch et al. 2000; Evans and Andersen 2006; Gomez and Wilson 2001; Hetherington 1996). These studies suggest that the relationship between performance outcomes and political evaluations is not uniform but varies systematically across individuals. A second critique of the reward-punishment model focuses on variation in the target of evaluation, emphasizing the extent to which voters spread credit and blame for economic outcomes across elected officials, public agencies, and private-sector actors (Peffley 1985; Peffley and Williams 1985; Rudolph 2003a; 2003b; 2006). This research questions whether simple referendum models of the vote are correct in tying responsibility judgments to the political executive since "before economic discontents can take on political significance, people must believe that it is the government's job to remedy them" (Peffley 1985, 192). A third approach to how publics evaluate policymakers also considers the attribution target. Instead of considering multiple targets, however, it examines the target's policy preferences and policy competencies (Budge and Farlie 1983; Hibbs 1977). In the United States, for example, Republican politicians are thought to be more concerned with—and therefore more competent at—creating a stable environment for investment than Democrats. Such policy orientations, in turn, shape public

\footnotetext{
${ }^{2}$ Normatively, the reward-punishment model provides a simple translation of theories of democratic accountability onto voter behavior in elections. Empirically, testing the theory requires no more than data on election outcomes
} 
tendencies to hold the parties to accounts. A rational electorate should not punish Republican office-holders for rising prices, the argument goes, since performance outcomes are not likely to be any better were the Democrats in control (Alesina 1987; Anderson 1995; Carlsen 2000; Dorussen and Taylor 2001; Hibbs 1977).

These critiques of the reward-punishment model are suggestive of how citizens might perceive and evaluate the room to maneuver. Consider, for example, the insights from research into individual heterogeneity. Insofar as it relies on temporally and spatially aggregated analyses of economic aggregates like factor endowments and factor specificity (Hiscox 2002) and on political institutions like the nature of electoral systems (Rogowski 1989), current political economy research is ill-equipped to teach us how citizens appreciate (understand) any constraints on policy or to link policy choices to macroeconomic outcomes. But the literature on individual heterogeneity in vote choice suggests that some citizens will be more focused on certain policies in making such evaluations. For instance, some will be more concerned with whether governments continued capacity to fight inflation than others (Scheve 2004). Insights from researchers in political psychology on motivated reasoning suggests that partisan factors, in particular, should affect how citizens view the room to maneuver (Kuklinski et al. forthcoming; Rudolph 2006). The use of partisan-motivated reasoning may lead some citizens to believe that their preferred party 1) possesses policy latitude and 2) is more competent than other parties at managing the open economy. Concomitantly, lesser preferred parties may be perceived as using their room to maneuver to create undesirable outcomes. This literature also alerts us to the importance of question wording in the relevant surveys. Proponents of the globalization thesis and revisionist arguments alike presume that national governments remain responsible for policy outcomes. Alternative targets of policy responsibility, such as businesses and other private 
sector actors and (especially) extra-national forces such as global business cycles, often are not included in the list of possible responses. Finally, insights from theories of accountability suggest that partisanship may bias how citizens perceive of policy efficacy.

In sum, if citizens do not perceive any room to maneuver, then they ought to attribute economic performance to market forces. And perhaps they ought to make no connection between the partisan identity (policy choices) of elected officials and economic outcomes. If citizens agree that governments retain the capacity to influence the economy-even when primed about economic globalization - then they ought to attribute performance to elected officials. This attribution, however, may be colored by partisan reasoning. Their most preferred party may get more credit for using their room to maneuver effectively than their least preferred party.

In what follows, we analyze the individual and partisan factors shaping responsibility attributions relative to economic globalization. We investigate the possibility that question wording affects citizens' beliefs about who is responsibility for economic conditions and then analyze how citizen's beliefs about room to maneuver affects (reflects) their political attitudes.

\section{Who's Responsible for the Economy? The Effect of Market Integration on Responsibility Attributions}

Data used in this study are from survey conducted through the Time-Sharing Experiments for the Social Sciences (TESS) project. ${ }^{3}$ The survey was administered to a random sample of 514 American adults in February 2005 by the Center for Survey Research at Indiana University.

The instrument underwent an extensive pretesting in order to improve response rate and item

\footnotetext{
${ }^{3}$ The telephone time for the module was awarded to Freeman. Time-Sharing Experiments for the Social Sciences, is supported by a grant from the N.S.F., Diana C. Mutz and Arthur Lupia, Principal Investigators. Additional information on the TESS program is available at www.experimentcentral.org.
} 
reliability. Its first part analyzes whether priming and response options affects subjects' attributions responsibility for economic performance.

\subsection{Responsibility Attribution Experiment 1: Replication of questions asked by ANES and} NBC/Wall Street Journal.

In the first experiment half the sample were randomly assigned to four groups. These groups then were questioned about who is responsible for the economy. In order to determine whether responses are influenced by how questions are worded, we varied question primes and response options for each group. ${ }^{4}$ Group 1 received a question identical to one asked in the 1998 American National Election Study (ANES): "Please tell me who you feel is most responsible for the economic conditions in the United States in the past few years, the Congress, the President, working people, or business people." This question allows us to analyze whether citizens attribute outcomes to elected officials or to private-sector actors. It also has the desirable property of leaving it up to the respondent as to whether "economic conditions in the past few years" have been either good or bad. The question might be criticized, however, for limiting response categories to domestic and non-market factors alone. In fact, there are surveys, one conducted by the NBC and the Wall Street Journal in 2001, that explicitly ask about the influence of "cycles" on economic performance. ${ }^{5}$ Accordingly, respondents in Group 2 were given a fifth response option: "national and international business cycles."

Neither the ANES nor the NBC/WSJ polls, however, make any reference to the constraints imposed on our government by the world economy. To determine if priming

\footnotetext{
${ }^{4}$ In this way, we inquire as to whether changes in wording or in the closed-ended response options causes respondents to select different options (see, e.g., Druckman 2001).

${ }^{5}$ The NBC/WSJ poll was conducted by Hart and Teeter Research Companies between January 13 and 15 in 2001. The question used in it was: "Through much of the 1990s, America enjoyed a strong economy. Which one of the following do you think was most responsible for the economy's success? Productivity of businesses and workers, the Clinton administration, Alan Greenspan and the Federal Reserve, the national and international business cycles,
} 
respondents with a reference to these constraints would alter their responses, two additional treatments were added to the experiment. A third, randomly selected group was primed to think about the international economy as follows: "In terms of trade and finance, the United States is now deeply involved in the world economy. In view of this, who is most responsible for the economic conditions in our country in the last few years, the Congress, the President, working people, or business people." Finally, a fourth group received both the priming about international market forces and the additional item from the NBC/WSJ poll. ${ }^{6}$

Table 1 reports the frequencies of each type of response in each of the four groups. ${ }^{7}$ For sake of comparison, we also report frequencies from the 1998 ANES question, as reported in Rudolph (2003b). Several points are of note. First, while responses for TESS Group 1 generally match closely with the 1998 ANES survey, more respondents in the former identified the president as responsible (31.1\% versus $21.5 \%)$, while fewer attributed economic conditions to working people $(6.8 \%$ compared to $16.1 \%){ }^{8}$ Second, the international economy primes have no effect on the distribution of responses. A $\chi^{2}$ statistic for the effect of priming for those groups

or the Republican Congress' policies?" We added only the item about national and international business cycles to the list in the ANES attribution of responsibility question.

${ }^{6}$ The questions are included in the appendix. Groups 1,2,3, and 4 were assigned randomly to questions $1.11,1.12$, 1.21 , and 1.22 , respectively.

${ }^{7}$ To prevent any response ordering effects from systematically biasing the results, the order in which response options were presented to subjects was randomized for the attribution question. As a test for ordering effects, we conducted difference of means tests comparing the mean for respondents who received the business cycles option first to the mean of the rest of the sample $(t=-0.513, p=0.608)$, the mean for respondents who received the business cycles option last to the mean for the remaining respondents $(t=0.535, p=0.593)$, and the mean for respondents who received the business cycles option first or last with the mean for those who received it second, third, or fourth $(\mathrm{t}=0.004, \mathrm{p}=0.997)$. All three comparisons are statistically insignificant, indicating that the randomization of the response options was effective in preventing systematic bias. Additionally, we performed a cross-tabulation of question responses about who is responsible for economic conditions and whether they received the "national and international business cycles" option first, fifth, or second through fourth. The resulting chi-square statistic failed to reject the null of no relationship between response ordering and the respondents' answers to who is responsible for economic conditions $\left(\chi^{2}=7.99, \mathrm{p}=0.435\right)$. This again suggests that the randomization was effective.

8 The first difference might be attributable to the divided government, which was present in 1998 but not 2005, and which previous research has shown to moderate accountability (Rudolph 2003a; Norpoth 2001). The second difference might be due to party control of the presidency, which was Democratic in 1998 and Republican in 2005. The argument would be that "working people" have more influence, and therefore are more responsible for economic conditions, under Democratic presidents (e.g., Hibbs 1977). 
which received it (Groups 3 and 4) against those which did not (Groups 1 and 2) fails to reject the null of no difference due to priming effects. ${ }^{9}$ Third, and most importantly, results show that a substantial number of respondents would attribute responsibility to national and international business cycles if given the opportunity to do so. When given the option (as in TESS Groups 2 and 4), about one-third of respondents assigned responsibility for the economy to national and international business cycles. In short, these results suggest that a substantial share of Americans attribute economic performance to markets and not policymakers. Therefore any model of the attribution process that omits consideration of the role of national and international business forces_e.g., Rudolph (2003b) —is incomplete. ${ }^{10}$

\section{<Table 1 about here>}

We next consider the determinants of citizens' target of responsibility attributions and to assess what effect, if any, the fifth response option has on these determinants. To do so, we estimate two multinomial choice models. The first combines respondents in TESS Groups 1 and 3 and estimates a four-choice model. The second combines respondents in TESS Groups 2 and 4 to estimate a five-choice model. Informed by research on motivated reasoning, our primary interest pertains to the effects of partisanship. Analyses therefore include dummy variables for

\footnotetext{
${ }^{9} \mathrm{~A}$ chi-square test reveals no significant relationship between priming and the results to the ANES attribution question with four response options in Groups 1 and $3\left(\chi^{2}=2.00\right.$, p-value $\left.=0.571\right)$. Similarly, a chi-square test with Groups 2 and 4 fails to reject the null of no relationship between the attribution question-with five choices, including "national and international business cycles" - and the priming language $\left(\chi^{2}=1.709, \mathrm{p}\right.$-value $\left.=0.789\right)$.

${ }^{10}$ Given the lack of priming effects, we can pool the results from Groups 1 and 3 and from Groups 2 and 4 to examine the degree to which the results of the attribution questions vary from the null hypothesis of an equal distribution among the response options. For Groups 1 and 2 with four response options, the expected frequency is 25 percent for each response option. We reject this null of an equal distribution $\left(\chi^{2}=22.64, p<0.001\right)$. Specifically, the "working people" option is below the expected value while Congress, business people, and the president are all above the expected values. Similarly, for Groups 2 and 4, we can reject the null of an equal distribution $\left(\chi^{2}=20.21, p<0.001\right)$. The categories Congress and working people are below the expected value while the president, business people, and business cycles are above the expected values. Both sets of results indicate that responses are not randomly distributed across response options provided.
} 
Republican identifiers, Democratic identifiers, and independents. ${ }^{11}$ We include three controls.

To assess whether one's position in the labor market biases how one assesses policy

responsibility, we include a dummy variable scored 1 for those who are employed full time and 0

for everyone else. Given their labor force participation, we expect that full time workers will be

more likely to attribute responsibility for economic outcomes to market actors (i.e., business

people and working people and, when provided the option, business cycles). Un- and under-

employed respondents should be more likely to associate economic outcomes to political elites

(The president and the Congress). We also control for education level, measured as a four-

category scale (less than high school, high school diploma, some training beyond high school,

college degree). Those with more formal education might be better able to recognize the indirect

connections between policy decisions and economic outcomes and, therefore, would be more

likely to attribute responsibility to market forces. ${ }^{12}$ Finally, in order to account for any

remaining priming effects, we include a dummy variable indicating whether or not respondents

received the prime. ${ }^{13}$

\footnotetext{
${ }^{11}$ Republicans (Democrats) are those identifying as strong or moderate Republicans (Democrats) on the standard ANES multi-item seven-point party identification scale. Pure independents and leaners are coded as Independent.

${ }^{12}$ In their reduced-form models of the British macro political economy, Sattler et al. (forthcoming; 2007) find connections between the macroeconomic outcomes and public opinion (aggregate incumbent vote intentions and executive approval) and between opinion and policy outcomes, but not between policy and the macroeconomy. The last of these hints at a fundamental limitation on what the average voter knows about how the economy works. ${ }^{13}$ We examined the effects of several other variables, including age, gender, income, and ideology. We also examined alternative codings for occupational status (e.g., employed/unemployed). Use of these alternative specifications and measures did not change the results reported in the text.
} 
We estimate the models using multinomial logit (MNL). ${ }^{14}$ Results are reported in Tables 2 (four choice model) and 3 (five choice model). In both cases "The President" is the reference category in the choice model, and Democratic identifiers are the baseline for partisanship. Results largely conform to expectations. In both tables, Republicans appear more likely to attribute responsibility to business people and to working people than do Democrats. Table 2 (the four-choice model) shows that education also has an effect, with more educated respondents less likely to attribute responsibility to the president. This role of education, however, is weakens when we consider "national and international business cycles" (Table 3). While employment status has no apparent impact in Table 2, Table 3 shows that full time workers are more likely assign responsibility to market forces than to the president.

\section{<Tables 2 and 3 about here>}

To better judge the magnitude of the effects of these predictors, Tables 4 and 5 report a set of expected choice probabilities for a hypothetical respondent who, unless otherwise noted, is a political independent, employed full time, and has some post-secondary education. These tables reveal three findings of interest. First consider partisanship. Without the business cycle option (Table 4), Republican identifiers attribute responsibility to the Congress with probability .38 , with "business people" following closely at .32 . When provided the additional response option, however (in Table 5), the probability that a Republican attributes responsibility to

\footnotetext{
${ }^{14}$ MNL makes the assumption of independence of irrelevant alternatives (IIA). To test this assumption, we performed seemingly unrelated estimation tests, a generalization of the Hausman test which relaxes the assumption of no correlation between the unrestricted and restricted estimates and therefore is appropriate for small sample sizes. To perform the test we first estimate the full unrestricted MNL model and retain parameter estimates. We then exclude one of the response options and reestimate the model and again retain parameter estimates. Finally, a hypothesis test is conducted to assess whether the coefficients vary statistically across the two models. Since the model in Table 2 has four response options, four simultaneous tests with the null that all corresponding beta coefficients are equal across the two models are necessary to compare the full model to a model with one of the response options excluded. The model in Table 3 has five response options, so five simultaneous hypothesis tests of corresponding coefficients are performed. The null hypothesis is that the MNL coefficients are statistically indistinguishable across the two models, indicating that IIA holds. The alternative hypothesis is that the MNL
} 
business cycles is .42 and the probability of selecting the Congress falls to just .12. Moreover, the probability that a Republican assigns responsibility to (the then Republican) president is estimated at .19 for the four choice model but only .08 for the five-choice model. Democrats, on the other hand, remain highly likely to select "the president," even when given the option of responding with "national and international business cycles." Partisanship, in short, biases one's assignment of policy responsibility.

Second, results show that the effect of one's position in the labor market is contingent on the response set. When not provided a "business cycle" option, employment status has no bearing at all on respondent choice. With a fifth response option, however, we find that full time workers are less likely than non-full time workers to select the president (first difference $=-.15$ ) but considerably more likely to select business cycles (first difference $=+.18$ ). Finally, consistent with Rudolph (2003b), education matters for the four-choice model. It has no apparent effect, however, once we consider business cycles. The .20 difference in expected probabilities of attributing economic performance to the president for those with only a high school diploma (.34) and those with a college degree or higher (.14) is statistically significant for the four-choice model in Table 4 but falls from significance once we consider business cycles in Table 5. This suggests that other factors, such as one's partisan biases, are more likely to shape responsibility attributions than simply one's ability to process a complex policymaking environment.

\section{<Tables 4 and 5 about here>}

\subsection{Responsibility Attribution Experiment 2: Replication of questions asked by British Election Panel Study and British Social Survey.}


As shown above, some surveys show that large segments of European publics doubt their governments have much capacity to influence their economies. To determine how American citizens respond to the questions asked in these surveys, four more groups were randomly constructed. These groups were read versions of two questions, one asked in 2001 by the British Election Panel Study (BEPS, Heath et al. 2002) and the other asked in the British Social Survey (BSS) in 1986. The former is, "In today's world-wide economy, how much influence do you think British governments have on Britain's economy?" In both versions of this question we substitute "American government" and "America's economy" in place of the British references. In one version, posed to TESS Group 5, we omitted the opening reference to "today's worldwide economy." This prime was left in for TESS Group 6. The BSS asked a more complicated, multipart question: "Some people say that British governments nowadays—of whichever partycan actually do very little to change things. Others say they can do quite a bit. Do you think British governments nowadays can do very little or quite a bit to a) keep prices down, b) reduce unemployment c) reduce taxes d) improve the standard of living e) improve health and human services and f) control wage and price increases?" We asked only about items a) and b). However, in view of the evidence that Americans support training programs for displaced workers (Scheve and Slaughter 2001), we added the following item: "World trade causes some American workers to lose their jobs. Do you think the American government can do very little or quite a bit to help these workers?" The identity of governments once more was changed from British to American, and we again varied the question with a world economy prime such that TESS Group 7 received no priming while TESS Group 8 was primed with "Some say that because of the world economy...,"15

\footnotetext{
${ }^{15}$ Groups 5, 6, 7, and 8 were randomly assigned to questions $1.31,1.32,1.41$ and 1.42 respectively.
} 
Results of these replications of the British surveys are reported in Tables 6 and 7. Priming again appears to have had little effect. Adding a reference to the world economy in the question from the BEPS decreased the frequency of the "A Great Deal" response given by Group 6. A chi-square test for differences between Group 6's responses and those of Group 5, however, is statistically insignificant $\left(\chi^{2}=4.281, p=0.233\right)$. Perhaps more important, however, is the comparison with both TESS Groups with the BEPS results. American respondents are much more convinced than their British counterparts that their government still has the capacity to influence the economy; a full $90 \%$ of the American groups respond positively to this question compared to only $53 \%$ of British respondents.

\section{$<$ Tables 6 and 7 about here>}

Turning to our replication of the BSS question in Table 7, the responses of the two sets of respondents on the government's ability to keep prices down, to reduce unemployment, and to help workers are very similar. It appears there may be some evidence of priming effects for Groups 7 and 8 on the unemployment item. Adding the reference to the world economy in the wording of this question increases the percent of respondents who answer "Very Little" from 32 to 41 ; a test for differences in the responses of the two groups, however, is statistically insignificant. ${ }^{16}$ Finally, there is no evidence that priming affects respondents views about the capacity of American governments to help displaced workers. A strong majority of respondents believe our governments have this capacity.

\section{The Room to Maneuver, Party Competencies, and Democratic Accountability}

\footnotetext{
${ }^{16}$ This is true of all three sets of questions for Groups 7 and 8 . For prices: chi-square $=0.0062$, p-value $=0.937$; for unemployment: chi-square $=1.054, \mathrm{p}$-value $=0.305$; for worker aid: chi-square $=0.394, \mathrm{p}$-value $=0.530$.
} 
Results from the two responsibility attributions experiments paint a mixed picture. On the one hand, Americans appear more willing to assign responsibility for policy outcomes to elected officials compared to publics in some European democracies. Given the United States' large domestic market and its status as world's largest economy, and considering the growth of regional economic integration in Europe, this result may not be a surprise. On the other hand, we find that a sizable minority of Americans believe there is, in fact, little their governments can do to influence market outcomes. About four in ten respondents, for example, claim there is "very little" the American government can do to affect prices or unemployment levels. Moreover, when given the option, fully one-third of respondents identify business cycles—not public- or private-sector actors - as chiefly responsible for national economic conditions. These findings raise important questions, particularly if this group of "non-believers" in the room to maneuver is growing as a share of the American public. What are the consequences of such beliefs for policymaker support? How do perceptions of a narrow policy room to maneuver affect public satisfaction with democracy in the United States? These questions are the focus of the experiments we report in this section.

\subsection{Who Thinks the Government's Hands are Tied?}

Who are these individuals who are convinced government no longer has the capacity to influence the economy? In order to distinguish subjects on the basis of their views on government economic policy efficacy, we used the following design. We first assigned the following subjects to a subset we label Believers in Room to Maneuver:

1) Subjects who, regardless of priming and(or) response itemization, attributed responsibility for the economy to the Congress or the President in Groups 1-4 (see Table 1); and 
2) Subjects who responded to the questions about government influence with "A great deal" or "Quite a lot" (Groups 5 \& 6); and

3) Subjects who answered in the affirmative to the each of the questions about government influence over prices, unemployment, and worker assistance (Groups $7 \& 8) .{ }^{17}$

This amounted to 296 subjects.

The subset of respondents who are Non-Believers in Room to Maneuver was taken only from those groups of subjects which received the primes for the world economy. ${ }^{18}$ These subjects had to satisfy each of the following conditions:

1) Subjects who, after hearing a reference to the world economy in the opening to their question, attributed responsibility for the economy to business people, working people, or national and economic business cycles (in Groups 3 \& 4); and

2) Subjects who said the American government had "Not very much" or "Hardly any influence" over America's economy (in Group 6), and

3) Subjects who answered in the negative to the multi-part question (in Group 8). ${ }^{19}$ By this assignment rule, a total of 82 subjects ( $22 \%$ of the total) were identified as not believing in the room to maneuver. ${ }^{20}$

To reiterate, our objective is three-fold. First, we seek to identify who these "non-

\footnotetext{
${ }^{17}$ As regards Groups $7 \&$ 8, by affirmative, we mean gave the answer "Quite a bit" to one or all three parts and otherwise did not reply "Very little" to any part of these questions (to the parts not answered "Quite a bit," a "Don't Know" response was permissible for assignment to the Believers in Room to Maneuver group).

${ }^{18}$ At the time the TESS experiment was designed, it was not clear that priming would have little effect. To ensure that its composition was not an artifact of question wording, the Nonbeliever group was constructed only from groups who received questions that referenced the world economy.

${ }^{19}$ For a member of Group 8 to be assigned to the Non-Believer subset, she would have to answer "Very little" to all three parts or else answer "Very little" only one or two of the parts with a "Don't Know" response for the remaining part(s).

${ }^{20}$ The survey was designed to rigorously isolate those who are solidly non-believers. Put another way, ours is a conservative estimate of the proportion of the American public who does not believe in the room to maneuver. Though measuring just $22 \%$ of our sample, we have reason to expect that the segment of the American public that perceives elected officials as having little to no policy room to maneuver will grow in the future. Findings from other, relatively more open economies, such as Britain and France, support this expectation.
} 
believers" are in terms of their partisan leanings, socioeconomic characteristics, and other attributes. Second, we examine whether membership in this non-believing minority affects political attitudes. And third, we probe more deeply in an effort to learn more about how "believers" and "non-believers" may differ in how they reason about the world economy and the choices confronting their government.

As regards the first of these objectives, we estimate a probit model predicting a dichotomous dependent variable, more specifically, whether an individual is a non-believer (1) or a believer in the room to maneuver (0). We include the same set of independent variables as in Tables 2 and 3-Republican, Independent, Education, and Employed full time. ${ }^{21}$ To account for the possibility that a subject's assignment to the "non-believer" group is affected by the questions they randomly received from Part I of the experiment, we include dummy variables for Groups 3, 4, and 8, with Group 6 set as the reference category.

Table 8 reports these results. It shows that partisanship has a strong effect on perceptions of policymaker control. Relative to Democrats (the reference partisanship category in the model), both Republicans and Independents are more likely to believe that their government no longer retains the room to maneuver. To see this, we hold all other variables constant and observe that, compared to an Democratic partisan, a Republican is $22 \%$ more likely to be a non-believer. ${ }^{22}$ We also find that the more educated are more likely to perceive that their government's hands are tied-for each unit increase in the 4-category education variable, the probability of being classified as a Non-Believer increases, on average, by about $8 \%$. For consistency with the

\footnotetext{
${ }^{21}$ Additional demographic indicators were examined, including gender, employment status, age, income, and liberal-conservative ideology, but none contributed to model fit or to individual parameter estimates.

${ }^{22}$ See column labeled "marginal impact" in Table 8. The marginal impact for the row labeled Republican compares the change in predicted probability that a Republican is a non-believer relative to that of a Democrat. The marginal impact for the row labeled Independent compares the change in predicted probability that an Independent is a nonbeliever relative to that of a Democrat.
} 
responsibility attributions analyses, we again include an indicator variable for whether the subject is employed full-time. Employment status, however, has no effect on the results. These findings are consistent with the ideas that Republicans generally believe that government intervention in the economy is more harmful than beneficial and that more educated citizens are more aware of the constraints the world economy impose on governments (Hellwig 2001). So, though composed of different samples, results reported in Table 8 complement those reported in section 3 above, particularly in terms of the role of partisanship.

\section{<Table 8 about here>}

\subsection{The Consequences of Room to Maneuver Beliefs for Political Attitudes}

We next consider the consequences of room to maneuver beliefs for political attitudes. We examine notions of policy efficacy directly by posing the following question to our subjects: "Which political party do you think does the best job of making economic policy for the world economy? Would you say the Democrats, the Republicans, or do both parties do an equally good job?" This question confronts an important implication of the room to maneuver debate in the international and comparative political economy: If it is the case that domestic political control over the economy remains strong, then we would expect partisan preferences to reflect differences over policy. Mosley $(2000,751)$, for example, asserts that even though world markets imposed constraints on governments management of prices and spending, British elections during the 1990 s were meaningful contests over economic policy. If this is true for the U.S. as well, then citizen attitudes should vary according to their policy (partisan) preferences, but only for those who maintain a belief in the room to maneuver.

We assess this expectation by cross-tabulating responses to the question on which party does the best job of making policy with the respondent's room to maneuver classification. Table 
9 presents the results. The table chi-square statistic is 9.03 , statistically significant at $p=0.01$.

This suggests that there is a relationship between belief in the room to maneuver (or not) and perceptions of which party is the more competent manager of economic globalization.

Specifically, among the Non-Believers, more said Republicans do the best job making economic policy than Democrats. Alternatively, among Believers in the Room to Maneuver, more said Democrats do the best job making economic policy than Republicans.

\section{<Table 9 about here>}

Tables 8 and 9 tell a story in which Republicans are more likely to be skeptical of government intervention in today's economy (Table 8) while, at the same time, these nonbelievers are more likely to point to Republican politicians as the more competent managers (Table 9). In short, Republican partisans tend to see the room to maneuver as undesirableperhaps because less room to maneuver is equivalent to less government intervention in the economy — and therefore they entrust Republican politicians to keep government involvement at a minimum.

We also investigate whether room to maneuver perceptions affect the extent to which citizens are satisfied with how accountability mechanisms in the United States. The following question was posed: "How satisfied are you when it comes to the way our democracy works in holding our officials accountable for the way they manage our economy through elections? Are you very satisfied, fairly satisfied, not very satisfied, or not at all satisfied."23 As above, we compare responses this question across the two room to maneuver groups. These results are

\footnotetext{
${ }^{23}$ This version of the question was posed to the Believer in Room to Maneuver group (Question 2.14). The NonBelievers group received a slightly different, though very similar, question: "When it comes to holding our elected officials accountable for the way they handle issues like trade-say through elections, are you very satisfied, somewhat satisfied, not too satisfied, or not at all satisfied with the way our democracy works in holding officials accountable for the way they manage our economy." (Question 2.24)
} 
reported in Table $10 .^{24}$ In brief, we find no relationship between perceptions of the room to maneuver and satisfaction with how democratic systems hold officials accountable for the economy via elections. Though these results appear as something of a surprise, it is important to recall the context in which the question was asked: The survey was conducted during the winter of 2005-6, a period in which Republicans were firmly in control of the executive and legislative branches of the federal government. And, according to many observers, they were much less interventionist than the Democrats might have been. Results regarding satisfaction with democracy can be interpreted to say that nonbelievers in the room to maneuver (many of which were Republican partisans, as Table 8 suggests) were happy that their elected officials were sensitive to the constraints imposed by the world economy and appreciative of the virtues of market forces. On the other hand, believers in government policy choice (more likely to be Democrats than Republicans or non-partisans) were confident that their most preferred party would return to office and exploit the government's capacity to influence prices and jobs as well as to help displaced workers.

\section{<Table 10 about here>}

\subsection{The Reasoning of Believers and Nonbelievers in the Room to Maneuver.}

Finally, in the second stage of the experiment believers and nonbelievers were asked a pair of tailored questions designed to better understand how they conceived of government capacity to affect the economy. ${ }^{25}$ To check that they did not see any decrease in government's capacity, Believers were asked, "Some people say in response to international economic forces,

\footnotetext{
${ }^{24}$ Pearson's chi-square test statistic for independence (1.89 with $3 \mathrm{df}$ ) is not statistically significant $(p=0.60)$. Since the satisfaction variable is ordinal, we also employed Kendall's tau-b statistic. This too failed to reject the null of that the rows and columns are independent $(\tau=0.019, p=0.70)$ We also collapsed the four-category response into two ("satisfied" and "not satisfied"). Results were qualitatively identical to what we report in Table 10.

${ }^{25}$ By "tailored" we mean a pair of questions based on the knowledge that they had been assigned as a result of their response in the first stage of the experiment to either the Believer or Nonbeliever group. (Questions 2.11 and 2.13; Questions 2.21 and 2.23)
} 
our government should do more to manage prices, create jobs, and help people whose livelihood is affected by trade. Others say that government does too much already. Which of these responses best describes what you think: A) Our government should do more nationally, B) The amount of government involvement in the national economy is about right, or C) The government does too much already." 26 Reflecting their belief in room to maneuver, $76 \%$ of these 296 respondents chose A or B. The extent of their belief in the desirability of and commitment to government intervention in the economy was reflected in these subjects' responses to a second tailored question about the accountability of the Federal Reserve Chairman, Alan Greenspan. When asked if Greenspan should be elected rather than appointed, $46 \%$ of the believers in the room to maneuver answered in the affirmative. ${ }^{27}$ This is remarkable because Greenspan is widely considered to have performed well as Fed Chair and the idea that monetary policy should be insulated from electoral politics is taken as virtually axiomatic in both economics and political science (see Freeman 2002; forthcoming).

Turning to the nonbelievers in the room to maneuver, these subjects were asked a pointed question about the nature of the constraints world markets impose on our government as well as a more general question about markets and policymaker discipline. The former question is informed by Mosley's (2000) study of the views of financial traders. Mosley found that, roughly speaking, traders preferred deficits of about $3 \%$ of GDP and inflation rates of about $2 \%$; governments could adopt any mix of policies as long as macroeconomic performance did not violate these deficit and inflation levels. When asked what would happen to jobs in the U.S. if the government increased spending and, by implication, violated these constraints, about $61 \%$ of Nonbelievers responded that more jobs would be created. This result is inconsistent with the idea

\footnotetext{
${ }^{26}$ As in all the questions in the experiment, subjects were allowed to respond with 'don't know' or to refuse an answer, though these options were not prompted by interviewers.
} 
that excess spending in the open economy would have dire consequences. But, in fact, this question is quite crude; it allows other interpretations such as the possibility that nonbelievers think government spending does have short-run effects but, over the longer-term, the economy is harmed by such policies. ${ }^{28}$ The responses of the nonbelievers to a question about market discipline were much more consistent with our expectations. The subjects in the nonbeliever group were asked the tailored question, "Some people say that the world economy strongly encourages our government to make good policies. Others say that the world economy strongly encourages our government to make policies that harm the American people. Which is closer to your opinion: Number one: The world economy strongly encourages our government to make good policies, Number two: The world economy strongly encourages our government to make policies that harm the American people." 56\% chose number one; $44 \%$ chose number 2 . This shows that nonbelievers in the room to maneuver tend to ascribe to the idea of market discipline.

\section{In Lieu of a Conclusion}

Results reported in this paper are preliminary. More analysis of the TESS data needs to be done. At this point, however, four broad findings deserve mention. First, priming for world economic forces appears to have little impact on responsibility attributions in the United States. If this is true in Britain, France and other countries, then it may be that Americans actually are more efficacious when it comes to government intervention in the national economy than their European counterparts. While this finding makes sense from the perspective of the unique position of the American economy in the world, it arguably is at odds with current political economy research which emphasizes how certain inclusive institutional arrangements

\footnotetext{
${ }^{27}$ This is question Q2.13. See the appendix for details about how this question was worded and asked.

${ }^{28}$ The intention was to try to test Mosley's findings in the minds of the nonbelievers. After many revisions of this question, Q2.21, neither Freeman nor the TESS staff was convinced this question was adequate for this purpose.
} 
(arrangements generally not associated with the United States' majoritarianism and small welfare state) aid in responsive and effective policymaking (e.g., Swank 2002).

Second, we find that a substantial minority of Americans fall into this category of nonbelievers in the room to maneuver. It should be remembered, moreover, that these individuals may have a strong preference for market allocation. They probably ascribe to the liberal view of free enterprise as means of realizing various kinds of rights, the best means to solve "the calculation problem," etc (Freeman and Nardulli, 2006). Rather than assuming that a weak level of policymaker control to necessarily be undesirable, students of comparative and international political economy must be willing to entertain that these individuals see the rise of international market forces and increases in market discipline as good things.

Third, the belief that markets reduce the credibility of policy intervention is not randomly distributed among the public. Rather, we find considerable heterogeneity in beliefs about the room to maneuver. In particular, partisanship has a strong effect, with Republican partisans less more likely to be nonbelievers. Our results also show that perceptions of policy efficacy are shaped by education levels (the more educated are more likely to see policymakers as constrained) and by labor market status (full-time workers less likely to attribute responsibility for policy outcomes to elected officials). To the extent that these differences become the bases of new electoral cleavages and future policy debates, we must learn more about the political implications of this heterogeneity.

Finally, our results speak to the central role of economic evaluations in mass politics in the United States. The workhorse model of electoral accountability asserts that when economic conditions deteriorate, the public holds the government responsible and removes the executive from office. In order for this sanctioning device to work, however, people must first believe that 
it is the government's job to ensure a stable and buoyant national economy. This point has not been lost on students of political behavior (Peffley 1985; Peffley and Williams 1985; Rudolph 2003b). Moreover, results presented here show how perceptions of economic conditions continue to matter in American elections - the economy matters because, as we show, a majority of citizens believe in the American government's capacity to influence the open economy. Future research must examine what implication, if any, this belief in the room to maneuver has for democratic accountability and policymaker responsiveness. 


\section{Appendix: Survey Design and Questions}

The design is divided into two parts. Part I is an assessment of priming effects with respect to citizen assessments of the room to maneuver. Part II is an analysis of the reasoning and satisfaction of citizens who indicate the room to maneuver does (not) exist. Percentages in brackets in part one indicate the size of each of the eight randomly-assigned sub-samples provided by the research design. The numbers of respondents assigned to each condition were not always exactly - but did approximate--one-eighth of the sample each. The subsamples for part two of the experiment are constructed from the responses in part one as indicated. Respondents were not explicitly offered "none," "don't know," or "refuse to answer" options. However, if they volunteered one of these responses, they were recorded in the data set and no follow up question attempt to elicit a fuller response was asked. In part one, at most 2 respondents answered None or Don't Know to any question. The numbers of these responses were slightly higher in part two. In the questions for Believers in Room to Maneuver, the maximum number of Don't Know responses was 8 and the maximum number of refusals was 5-for Q2.12 (N=296); in part two the maximum Don't Knows was 7 and Refuse to Answers was one-to Q2.21 ( $\mathrm{N}=82)$.

\section{Part I. The Responsibility Attribution Experiment}

\subsection{Variation in choices, responsibility attribution}

[12.5\%] Q1.11 Please tell me who you feel is most responsible for the economic conditions in the United States in the last few years. Is it: ${ }^{29}$
A. The Congress
B. The President
C. Working People
D. Business People

[12.5\%] Q1.12 Please tell me who you feel is most responsible for the economic conditions in the United States in the last few years. Is it:
A. The Congress
B. The President
C. Working people
D. Business people
E. National and international business cycles

\footnotetext{
${ }^{29}$ The order in which the substantive response options were offered was randomized for Q1.11, Q1.12, Q1.21, and Q1.22.
} 


\subsection{Variation in question wording (international economic forces), responsibility attribution}

[12.5\%] Q1.21 In terms of trade and finance, the United States now is deeply involved in the world economy. In view of this, who is most responsible for the economic conditions in our country in the last few years. Is it:
A. The Congress
B. The President
C. Working people
D. Business people

[12.5\%] Q1.22 In terms of trade and finance, the United States now is deeply involved in the world economy. In view of this, who is most responsible for the economic conditions in our country in the last few years. Is it:
A. The Congress
B. The President
C. Working people
D. Business people
E. National and international business cycles

1.3 Replication of question on British Election Panel Study for U.S. with and without reference to international economic forces

[12.5\%] Q1.31 How much influence do you think the American government has on America's economy? Does the American government have a great deal, quite a lot, not very much or hardly any influence?
A. A great deal
B. Quite a lot
C. Not very much
D. Hardly any

[12.5\%] Q1.32 In today's worldwide economy, how much influence do you think the American government has on America's economy? Does the American government have a great deal, quite a lot, not very much or hardly any influence?
A. A great deal
B. Quite a lot
C. Not very much
D. Hardly any

1.4 Replication of question from Social Survey (Gallup Poll) Ltd. Great Britain with and without reference to international economic forces

[12.5\%] Q1.41 Some people say that American governments nowadays - of whichever partycan actually do very little to change things. Others say they can do quite a bit. 
Q1.411. Do you think that American governments nowadays can do very little or quite a bit to keep prices down?
A. Very little
B. Quite a bit

Q1.412. Do you think that American governments nowadays can do very little or quite a bit to reduce unemployment?
A. Very little
B. Quite a bit

Q1.413. World trade causes some American workers to lose their jobs. Do you think the American government can do very little or quite a bit to help these workers?
A. Very little
B. Quite a bit

[12.5\%]Q1.42. Some people say that because of the influence of the world economy that American governments nowadays - of whichever party — can actually do very little to change things. Others say they can do quite a bit.

Q1.421, Do you think that American governments nowadays can do very little or quite a bit to keep prices down?
A. Very little
B. Quite a bit

Q1.422. Do you think that American governments nowadays can do very little or quite a bit to reduce unemployment?
A. Very little
B. Quite a bit

Q1.423. World trade causes some American workers to lose their jobs. Do you think the American government can do very little or quite a bit to help these workers?
A. Very little
B. Quite a bit 


\section{Part II. The Room to Maneuver Experiment}

2.1 Citizens who affirm that American governments still retain room to maneuver in the world economy (Subsample of those who gave responses: Q1.11 (A,B), Q1.12 (A,B), Q1.21 (A,B), Q1.22 (A,B), Q1.31 (A,B), Q1.32 (A,B); at least one of Q1.4.11, Q1.4.12, Q1.4.13 (B) and, at the same time, to the others, Don't Know; at least one of Q1.4.21, Q1.4.22, Q1.4.23 (B) and, at the same time, to the others, Don't Know. ${ }^{30}$

Q2.11 Some people say in response to international economic forces, our government should do more to manage prices, create jobs, and help people whose livelihood is affected by trade. Others say that the government does too much already. Which of these three statements best describes what you think?

A. Our government should do more nationally

B. The amount of government involvement in the national economy is about right

C. The government does too much already

Q2.12 Which political party do you think does the best job of making economic policy for the world economy? Would you say the Democrats, Republicans, or do both parties do an equally good job?
A. The Democrats
B. The Republicans
C. Both parties do an equally good job

Q2.13 Alan Greenspan is the Chairman of the Federal Reserve System; he oversees the making of monetary policy. But we don't elect Alan Greenspan. He is appointed. Some people think that, in view of the important role the Chairman of the Federal Reserve System plays in responding to the world economy, people should elect this person. Do you agree or disagree that people should elect the head of the Federal Reserve? ${ }^{31}$
A. Strongly agree ${ }^{32}$
B. Somewhat agree
C. Somewhat disagree
D. Strongly disagree

\footnotetext{
${ }^{30}$ For question Q1.42, to be included in this second part of the experiment, if respondents answer B to only one of | the three subitems, then the same individuals must answer Don't know to the other two. In other words Believers in Room to maneuver must not give any conflicting answers among the three subitems.

${ }^{31}$ If asked to define monetary policy, interviewers were instructed to say, "Monetary policy is the process of managing a nation's money supply to achieve specific goals - such as constraining inflation, achieving full employment or more well-being." If respondents asked about the pending appointment of Ben Bernanke as Federal Reserve Chairperson, they were reminded that at the time of the survey, Alan Greenspan still served as Chairperson. 32 This was a branching question in which respondents were first asked whether they agreed or disagreed and then asked a follow-up question regarding the strength of their agreement [disagreement].
} 
Q2.14. How satisfied are you when it comes to the way our democracy works in holding our officials accountable for the way they manage our economy through elections? Are you very satisfied, somewhat satisfied, not too satisfied, or not at all satisfied?
A. Very satisfied
B. Somewhat satisfied
C. Not too satisfied
D. Not at all satisfied

2.2 Citizens who do not believe American governments have room to maneuver in the world economy (Subsample of those who gave responses: Q1.21 (CD), Q1.22(CDE), Q1.32 (CD); at least one of Q1.4.21, Q1.4.22, Q1.4.23 (A) and, at the same time, to the others Don't Know. ${ }^{33}$

Q2.21. International investors and traders seem to want the United States' federal budget deficit to be about three per cent of our national income and inflation in our country to be about two percent. Suppose our government tried to achieve some different economic goals, say by increasing government spending and making our deficit bigger than three per cent. Which of these is more likely to happen-more government spending would REDUCE the number of jobs in our country, or more government spending would INCREASE the number of jobs in our country?

A. More jobs would reduce the number of jobs in our country

B. More government spending would increase the number of jobs in our country

C. Depends on how it is spent

Q2.22 Which political party do you think does the best job of making economic policy for the world economy? Would you say the Democrats, the Republicans or both of the parties do an equally good job?
A. The Democrats
B. The Republicans
C. Both parties do an equally good job

\footnotetext{
${ }^{33}$ For Questions 1.42, these respondents must give at least one A response and for these same individuals the other responses both must be "Don't Know."
} 
Q2.23. Some say that the world economy strongly encourages our government to make good policies. Others say that the world economy strongly encourages our government to make policies that harm the American people. Which is closer to your opinion? Number one: The world economy strongly encourages our government to make GOOD policies, Number two: The world economy strongly encourages our government to make policies that HARM the American people

A. World economy encourages our government to make good policies

B. World economy encourages our government to make policies that harm the American People

Q2.24. When it comes to holding our elected officials accountable for the way they handle issues like trade - say through elections, are you very satisfied, somewhat satisfied, not too satisfied, or not at all satisfied with the way our democracy works in holding officials accountable for the way they manage our economy?
A. Very satisfied
B. Somewhat satisfied
C. Not too satisfied
D. Not at all satisfied 


\section{References}

Alesina, Alberto. 1987. "Macroeconomic Policy in a Two-Party System as a Repeated Game." Quarterly Journal of Economics 102: 651-78.

Anderson, Christopher J. 1995. "The Dynamics of Public Support for Coalition Governments." Comparative Political Studies 28(3): 350-83.

Baker, Andy. 2005. "Who Wants to Globalize? Consumer Tastes and Labor Markets in a Theory of Trade Policy Benefits." American Journal of Political Science 49(4): 924-38.

Bearce, David. 2007. Monetary Divergence: Domestic Policy Autonomy in the Post-Bretton Woods Era. Michigan Studies in International Political Economy. Ann Arbor, MI: University of Michigan Press

Boix, Carles. 1998. Political Parties, Growth and Equality: Conservative and Social Democratic Economic Strategies in the World Economy. Cambridge: Cambridge University Press.

Carlsen, Fredrik. 2000. "Unemployment, Inflation, and Government Popularity - Are there Partisan Effects?" Electoral Studies 19: 141-50.

Centre d'Etudes de al Vie Politique Française (CEVIPOF), Centre d'Informatisation des Données Socio-Politiques (CIDSP), and Centre de Recherches Administratives, Politiques et Sociales (CRAPS). 2001. French National Election Study, 1997 [Computer file]. ICPSR version. Ann Arbor, MI: ICPSR [distributor].

Clark, William Roberts. 2003. Capitalism not Globalism. Ann Arbor, MI: University of Michigan Press.

Dorussen, Han, and Michael Taylor. 2001. "The Political Context of Issue-Priority Voting." Electoral Studies 20: 399-426.

Druckman, James N. 2001. "The Implications of Framing Effects for Citizen Competence." Political Behavior 23(3): 225-56.

Duch, Raymond M., Harvey D. Palmer, and Christopher J. Anderson. 2000. "Heterogeneity in Perceptions of National Economic Conditions." American Journal of Political Science 44(4): 635-52.

Evans, Geoffrey, and Robert Andersen. 2006. "The Political Conditioning of Economic Perceptions." Journal of Politics 68(1): 194-207.

Franzese, Robert F, Jr. 2002. Macroeconomic Policies of Developed Democracies. Cambridge: Cambridge University Press.

Freeman, John. R. 2002. "Competing Commitments: Technocracy and Democracy in the Design Monetary Institutions." International Organization, 56(4): 889-910.

Freeman, John R. Forthcoming, "Democracy and Markets: An Agenda" in Democracy and Markets in the Twenty First Century P. Nardulli editor. University of Illinois Press.

Freeman, John R. and Peter Nardulli. 2006. "The Concept of Free Enterprise." Center for the Study of Democratic Governance. The University of Illinois. (ww.csdg.uiuc.edu)

Garrett, Geoffrey. 1998. Partisan Politics in the Global Economy. Cambridge: Cambridge University Press.

Gomez, Brad T., and Matthew J. Wilson. 2001. "Political Sophistication and Economic Voting in the American Electorate: A Theory of Heterogeneous Attribution." American Journal of Political Science 45(4): 899-914. 
Hainmuller, Jens, and Michael J. Hiscox. 2006. "Learning to Love Globalization: Education and Individual Attitudes toward International Trade." International Organization.

Forthcoming.

Hall, Peter A., and David Soskice, eds. 2001. Varieties of Capitalism: The Institutional Foundations of Comparative Advantage. Oxford: Oxford University Press.

Hansen, Susan B. 1999. "Life is Not Fair: Governors' Job Performance and State Unemployment." Political Research Quarterly 52(1): 167-188.

Heath, Anthony, Roger Jowell, and John Curtice. 2002. British Election Panel Study, 19972001; Waves 1 to 8 [computer file]. UK Data Archive version, University of Essex, Colchester.

Hellwig, Timothy T. 2001. "Interdependence, Government Constraints, and Economic Voting," Journal of Politics 63(4):1141-62.

Hellwig, Timothy, and David Samuels. 2007. "Voting in Open Economies: The Electoral Consequences of Globalization." Comparative Political Studies 40(3): 283-306.

Hetherington, Mark J. 1996. American Journal of Political Science.

Hibbs, Douglas A., Jr. 1977. "Political Parties and Macroeconomic Policy." American Political Science Review 71(4):1467-87.

Hiscox, Michael J. 2002. International Trade and Political Conflict: Commerce, Coalitions, and Mobility. Princeton, NJ: Princeton University Press.

Hiscox, Michael J. 2006. "Through a Glass and Darkly: Attitudes Toward International Trade and the Curious Effects of Issue Framing." International Organization.

Iversen, Torben. 2005. Capitalism, Welfare, and Democracy. Cambridge: Cambridge University Press.

Iversen, Torben, and Thomas Cusack. 2000. "The Causes of Welfare State Expansion: Deindustrialization or Globalization?" World Politics 52(April): 313-49.

Kaltenthaler, Karl C., Ronald D. Gelleny, and Stephen J. Ceccoli. 2004. "Explaining Citizen Support for Trade Liberalization.” International Studies Quarterly 48(4): 829-51.

Korpi, Walter, and Joakim Palme. 2003. "New Politics and Class Politics in the Context of Austerity and Globalization: Welfare State Regress in 18 Countries, 1975-95." American Political Science Review, 97 (3): 425-46.

Kuklinski, James, Buddy Peyton, and Paul J. Quirk. 2006. "Issues, Information Flows, and Cognitive Capacities: Democratic Citizenship in a Global Era.” In Peter Nardulli, ed., Democracy in the Twenty First Century.

Kwon, Hyeok Yong. 2004. "Explaining New Left Voters: Economic Insecurity and Voter Transition in Britain." Paper presented at the annual meeting of the The Midwest Political Science Association, Chicago.

Mayda, Anna Maria, and Dani Rodrik. 2005. "Why are Some People (and Countries) More Protectionist than Others?" European Economic Review, 49(6), 1393-430.

Mishra, Ramesh. 1999. Globalization and the Welfare State. New York: Edward Elgar.

Moses, Jonathan W. 2000. OPEN States in the Global Economy: The Political Economy of Small- State Macroeconomic Management. New York: St. Martin's Press.

Mosley, Layna (2000) "Room to Move: International Financial Markets and National Welfare States" International Organization 54(4): 737-773.

Mughan, Anthony, Clive Bean and Ian McAllister. 2003. "Economic Globalization, Job Insecurity and the Populist Reaction." Electoral Studies 22(4): 617-33. 
Norpoth, Helmut. 2001. "Divided Government and Economic Voting." Journal of Politics 58(3): 776-92.

Peffley, Mark A. 1985. "The Voter as Juror: Attributing Responsibility for Economic Problems." In H. Eulau and M. Lewis-Beck, eds., Economic Conditions and Electoral Outcomes. New York: Agathon Press.

Peffley, Mark A. and John T. Williams. 1985. "Attributing Presidential Responsibility for National Economic Problems." American Politics Quarterly 13(4): 393-425.

Pierson, Paul. 2001. "Post-industrial Pressures on the Mature Welfare States." In P. Pierson, ed., The New Politics of the Welfare State. New York: Oxford University Press, pp. 80104.

Rogowski, Ronald. 1989. Commerce and Coalitions: How Trade Affects Domestic Political Alignments. Princeton, NJ: Princeton University Press.

Rudolph, Thomas J. 2003a. "Institutional Context and the Assignment of Political Responsibility." Journal of Politics 65(1): 190-215.

Rudolph, Thomas J. 2003b. "Who's Responsible for the Economy? The Formation and Consequences of Responsibility Attributions.” American Journal of Political Science 47(4): 698-713.

Rudolph, Thomas J. 2006. "Triangulating Political Responsibility: The Motivated Formation of Responsibility Judgments." Political Psychology 27(1): 99-122.

Ruggie, John G. 1982. "International Regimes, Transactions, and Change: Embedded Liberalism in the Postwar Economic Order." International Organization 36(2):195-231.

Sattler, Thomas, John. R. Freeman, and Patrick Brandt. forthcoming. "Political Accountability And the Room to Maneuver: The Search for a Causal Chain," Comparative Political Studies.

Sattler, Thomas, Patrick Brandt, and John Freeman (2007) "Economic Policy, Political Accountability an the Room to Maneuver." Paper presented at conferences on the International Political Economy of Finance, The University of Konstanz, January and the Atlanta Federal Reserve Bank, February.

Scheve, Kenneth. 2004. "Public Inflation Aversion and the Political Economy of Macroeconomic Policymaking." International Organization 58(1):1-34.

Scheve, Kenneth, and Mathew Slaughter 2001. Globalization and the Perceptions of American Workers Washington DC The Institute for International Economics.

Strange, Susan. 1996. The Retreat of the State: The Diffusion of Power in the World Economy. New York: Cambridge University Press.

Swank, Duane. 2002. Global Capital, Political Institutions, and Policy Change in Developed Welfare States. Cambridge: Cambridge University Press. 
Table 1. Responsibility Attributions for National Economic Conditions

\begin{tabular}{|c|c|c|c|c|c|}
\hline & $\begin{array}{c}\text { ANES } \\
\mathbf{1 9 9 8} \\
\mathrm{N}=1121\end{array}$ & $\begin{array}{c}\text { TESS } \\
\text { Group 1 } \\
\mathrm{N}=74\end{array}$ & $\begin{array}{c}\text { TESS } \\
\text { Group } 2 \\
\text { (Option) } \\
\mathrm{N}=56\end{array}$ & $\begin{array}{c}\text { TESS } \\
\text { Group } 3 \\
\text { (Prime) } \\
\mathrm{N}=64\end{array}$ & $\begin{array}{c}\text { TESS } \\
\text { Group 4 } \\
\text { (Option \& } \\
\text { Prime) } \\
\mathrm{N}=60\end{array}$ \\
\hline Congress & 30.5 & 33.8 & 16.1 & 32.3 & 13.3 \\
\hline President & 21.5 & 31.1 & 19.6 & 21.5 & 23.3 \\
\hline Working People & 16.1 & 6.8 & 10.7 & 9.4 & 6.7 \\
\hline Business People & 31.8 & 28.4 & 17.8 & 35.9 & 25.0 \\
\hline Nat'1 \& Int'1 Business Cycles & NA & NA & 35.7 & NA & 31.7 \\
\hline
\end{tabular}

Sources: 1998 American National Election Study and 2005 TESS program.

Note: Cells report percentages. Respondents who refused to answer, who answered "Don't know," or who volunteered other responses are not reported. This equaled less than two percent of TESS respondents. 
Table 2. MNL Estimates of Responsibility without National and International Business Cycles response option

\begin{tabular}{lccc}
\hline & $\begin{array}{c}\text { Business People } \\
\text { / President }\end{array}$ & $\begin{array}{c}\text { Congress / } \\
\text { President }\end{array}$ & $\begin{array}{c}\text { Working People } \\
\text { / President }\end{array}$ \\
\hline Republican & $1.191^{* *}$ & $1.418^{* *}$ & $1.879 * *$ \\
Independent & $(.582)$ & $(.585)$ & $(.876)$ \\
& .950 & $1.386^{* *}$ & .241 \\
Employed Full Time & $.665)$ & $(.650)$ & $(1.292)$ \\
& .520 & .373 & .793 \\
Education & $(.512)$ & $(.509)$ & $(.849)$ \\
& $.597 * *$ & $.559 * *$ & $1.100^{*}$ \\
World Economy Prime & $(.283)$ & $(.280)$ & $(.573)$ \\
& .971 & .692 & 1.264 \\
Constant & $(.514)$ & $(.515)$ & $(.798)$ \\
N & $-2.332^{* *}$ & $-2.210^{* *}$ & $-5.549 * *$ \\
LR statistic & $(.730)$ & $(.722)$ & $(1.601)$ \\
Pseudo R2 & 129 & & \\
\hline
\end{tabular}

Source: 2005 TESS study

Note: Cells report multinomial logit estimates with standard errors in parentheses. The President is the reference category. $* p<.10, * * p<.05,2$-tailed tests. 
Table 3. MNL Estimates of Responsibility with National and International Business Cycles response option

\begin{tabular}{lcccc}
\hline & $\begin{array}{c}\text { Business } \\
\text { People / } \\
\text { President }\end{array}$ & $\begin{array}{c}\text { Congress / } \\
\text { President }\end{array}$ & $\begin{array}{c}\text { Working } \\
\text { People / } \\
\text { President }\end{array}$ & $\begin{array}{c}\text { National \& } \\
\text { Int'l Business } \\
\text { Cycles/ } \\
\text { President }\end{array}$ \\
\hline Republican & $2.050^{* *}$ & $1.523^{*}$ & $1.870^{*}$ & $1.703^{* *}$ \\
& $(.796)$ & $(.900)$ & $(1.022)$ & $(.754)$ \\
Independent & 1.180 & 1.197 & 1.183 & 1.408 \\
& $(.806)$ & $(.892)$ & $(1.065)$ & $(.729)$ \\
Employed Full Time & .934 & .395 & 1.464 & $1.433^{* *}$ \\
& $(.655)$ & $(.739)$ & $(.858)$ & $(.621)$ \\
Education & $.650^{*}$ & -.134 & .180 & .502 \\
& $(.345)$ & $(.377)$ & $(.432)$ & $(.323)$ \\
World Economy Prime & .618 & -.186 & -.065 & .030 \\
& $(.645)$ & $(.726)$ & $(.820)$ & $(.607)$ \\
Constant & $-3.063^{* *}$ & -1.214 & $-2.908^{* *}$ & $-2.360^{* *}$ \\
& $(1.060)$ & $(1.080)$ & $(1.310)$ & $(.965)$ \\
$\mathrm{N}$ & 106 & & & \\
LR statistic & 27.78 & & & \\
Pseudo R2 & 0.09 & & & \\
\hline
\end{tabular}

Source: 2005 TESS study

Note: Cells report multinomial logit estimates with standard errors in parentheses. The President is the reference category. $* p<.10, * * p<.05,2$-tailed test 
Table 4. Predicted Probabilities of Responsibility Attributions, 4 Choice Model

\begin{tabular}{lcccc}
\hline & Congress & President & $\begin{array}{c}\text { Working } \\
\text { People }\end{array}$ & $\begin{array}{c}\text { Business } \\
\text { People }\end{array}$ \\
\hline Republican & .38 & .19 & .11 & .32 \\
& $(.10)$ & $(.07)$ & $(.07)$ & $(.09)$ \\
Democrat & .23 & .46 & .04 & .26 \\
& $(.08)$ & $(.11)$ & $(.05)$ & $(.09)$ \\
Employed full time & .42 & .23 & .04 & .31 \\
& $(.10)$ & $(.10)$ & $(.05)$ & $(.10)$ \\
Not employed full time & .40 & .31 & .03 & .26 \\
& $. .11)$ & $(.11)$ & $(.03)$ & $(.09)$ \\
First difference & .02 & -.08 & .01 & .05 \\
& $(.10)$ & $(.08)$ & $(.04)$ & $(.08)$ \\
High School & & & & \\
& .37 & .34 & .03 & .26 \\
College degree or more & $. .12)$ & $(.13)$ & $(.05)$ & $(.11)$ \\
First difference & .45 & .14 & .07 & .34 \\
& $(.11)$ & $. .07)$ & $(.07)$ & $(.10)$ \\
& -.09 & $.20^{* *}$ & -.04 & -.08 \\
& $(.11)$ & $(.10)$ & $(.06)$ & $(.10)$ \\
\hline
\end{tabular}

Note: Table entries are the expected probabilities of each responsibility attribution given specified combinations of the row variables with standard errors in paretheses. Cell entries are obtained by manipulating the value of the row variable while holding all other variable values to the following: world economy prime $=0$, Republican $=0$, Independent $=1$, Education $=2$ (some post-secondary education), Employed full time $=1$. Using CLARIFY (King et al 2000), we then calculate the mean and standard deviation of the predicted probabilities by taking 1000 draws from the multivariate normal distribution of the estimated parameters from Table 2. $* * p<.05$, $* p<.10$ for first differences. 
Table 5. Expected Probabilities of Responsibility Attributions, 5 Choice Model

\begin{tabular}{|c|c|c|c|c|c|}
\hline & Congress & President & $\begin{array}{c}\text { Working } \\
\text { People }\end{array}$ & $\begin{array}{c}\text { Business } \\
\text { People }\end{array}$ & $\begin{array}{c}\text { National and } \\
\text { Int'l Business } \\
\text { Cycles }\end{array}$ \\
\hline Republican & $\begin{array}{c}.12 \\
(.06)\end{array}$ & $\begin{array}{c}.08 \\
(.05)\end{array}$ & $\begin{array}{c}.16 \\
(.07)\end{array}$ & $\begin{array}{c}.24 \\
(.08)\end{array}$ & $\begin{array}{c}.41 \\
(.10)\end{array}$ \\
\hline Democrat & $\begin{array}{c}.12 \\
(.08)\end{array}$ & $\begin{array}{c}.30 \\
(.11)\end{array}$ & $\begin{array}{l}.12 \\
(.09)\end{array}$ & $\begin{array}{c}.14 \\
(.08)\end{array}$ & $\begin{array}{c}.32 \\
(.11)\end{array}$ \\
\hline Employed full time & $\begin{array}{c}.13 \\
(.07)\end{array}$ & $\begin{array}{c}.12 \\
(.06)\end{array}$ & $\begin{array}{c}.13 \\
(.08)\end{array}$ & $\begin{array}{c}.16 \\
(.07)\end{array}$ & $\begin{array}{c}.46 \\
(.11)\end{array}$ \\
\hline Not employed full time & $\begin{array}{c}.21 \\
(.10)\end{array}$ & $\begin{array}{c}.27 \\
(.11)\end{array}$ & $\begin{array}{c}.08 \\
(.07)\end{array}$ & $\begin{array}{c}.16 \\
(.08)\end{array}$ & $\begin{array}{c}.27 \\
(.10)\end{array}$ \\
\hline First difference & $\begin{array}{l}-.08 \\
(.09)\end{array}$ & $\begin{array}{c}-.15^{* *} \\
(09)\end{array}$ & $\begin{array}{c}.05 \\
(.08)\end{array}$ & $\begin{array}{c}.00 \\
(.08)\end{array}$ & $\begin{array}{l}.18 * \\
(.11)\end{array}$ \\
\hline High School & $\begin{array}{c}.20 \\
(.11)\end{array}$ & $\begin{array}{c}.16 \\
(.09)\end{array}$ & $\begin{array}{l}.15 \\
(.10)\end{array}$ & $\begin{array}{c}.12 \\
(.06)\end{array}$ & $\begin{array}{c}.37 \\
(.12)\end{array}$ \\
\hline College degree or more & $\begin{array}{c}.08 \\
(.06)\end{array}$ & $\begin{array}{c}.08 \\
(06)\end{array}$ & $\begin{array}{c}.11 \\
(.08)\end{array}$ & $\begin{array}{c}.21 \\
(.09)\end{array}$ & $\begin{array}{c}.51 \\
(.12)\end{array}$ \\
\hline First difference & $\begin{array}{c}.12 \\
(.16)\end{array}$ & $\begin{array}{c}.07 \\
(.07)\end{array}$ & $\begin{array}{c}.04 \\
(.09)\end{array}$ & $\begin{array}{l}-.09 \\
(.07)\end{array}$ & $\begin{array}{l}-.13 \\
(.12)\end{array}$ \\
\hline
\end{tabular}

Note: Table entries are the expected probabilities of each responsibility attribution given specified combinations of the row variables with standard errors in paretheses. Cell entries are obtained by manipulating the value of the row variable while holding all other variable values to the following: world economy prime $=0$, Republican $=0$, Independent $=1$, Education $=2$ (some post-secondary education), Employed full time $=1$. Using CLARIFY (King et al 2000), we then calculate the mean and standard deviation of the predicted probabilities by taking 1000 draws from the multivariate normal distribution of the estimated parameters from Table 3 . ** $p<.05$, $* p<.10$ for first differences. 
Table 6. Influence of Government on National Economy

\begin{tabular}{lccc}
\hline & $\begin{array}{c}\text { BEPS 2001 } \\
\text { N = 2333 }\end{array}$ & $\begin{array}{c}\text { TESS Group 5 } \\
\mathbf{N = 7 1}\end{array}$ & $\begin{array}{c}\text { TESS Group 6 } \\
\mathbf{N = 6 1}\end{array}$ \\
\hline A Great Deal & 9.0 & 47.9 & 32.8 \\
Quite A Lot & 44.4 & 42.3 & 57.4 \\
Not Very Much & 38.2 & 8.5 & 9.8 \\
Hardly Any & 5.2 & 1.4 & - \\
Don't Know & 3.1 & - & - \\
\hline
\end{tabular}

Sources: 2001 British Election Panel Study and 2005 TESS program

Note: Cells report percentages. The BEPS question wording is, "In today's world-wide economy, how much influence do you think British governments have on the Britain's economy." Both TESS groups were asked about the influence of the American government on America's economy. TESS Group 6 heard the same wording used the British survey. The prime "In today's world-wide economy" was omitted from the question posed to the individuals in TESS Group 5. 
Table 7. Effectiveness of Government's Economic Policy

\begin{tabular}{llccc}
\hline $\begin{array}{l}\text { Ability of Government } \\
\text { to: }\end{array}$ & $\begin{array}{c}\text { BSS 1996 } \\
\mathbf{N = 1 0 0 0}\end{array}$ & $\begin{array}{c}\text { TESS Group 7 } \\
\mathbf{N = 6 3}\end{array}$ & $\begin{array}{c}\text { TESS Group 8 } \\
\mathbf{N = 5 9}\end{array}$ \\
\hline Keep prices down & Quite A Bit & 62.0 & 60.3 & 61.0 \\
& Very Little & 33.0 & 39.7 & 39.0 \\
& Don't Know & 5.0 & - & - \\
Reduce unemployment & & & & \\
& Quite A Bit & 61.0 & 68.3 & 59.3 \\
& Very Little & 34.0 & 31.7 & 40.7 \\
& Don't Know & 5.0 & - & - \\
Help workers & Quite A Bit & - & 76.2 & 71.2 \\
& Very Little & - & 23.8 & 28.8 \\
& Don't Know & - & - & - \\
\hline
\end{tabular}

Sources: 1996 British Social Survey and 2005 TESS program

Notes: Cells report percentages. The size of the British survey is given as approximate; the percents for the BSS column therefore also are approximate. The question used in the British Social Survey is, "Some people say that British Governments nowadays—of whichever partycan actually do very little to change things. Others say they can do quite a bit. Do you think that British governments nowadays can do very little or quite a bit: to keep prices down, to reduce unemployment, to reduce taxes, to improve the general standard of living, to improve the health and social services and to control wages and salary increases." For the TESS study, we only asked about prices and unemployment and added an additional item, "World trade causes some American workers to lose their jobs. Do you think the American government can do very little or quite a bit to help these workers?" For both TESS groups respondents were asked about the capacity of American governments to achieve these three outcomes. The wording for TESS Group 7 was otherwise identical to the BSS. TESS Group 8 was primed with the opening: "Some people say that because of the influence of the world economy..." 
Table 8. Probit Model for Non-Believers in Room to Maneuver

Dependent variable: 1 = Non-Believers in Room to Maneuver, 0 = Believers in Room to Maneuver

\begin{tabular}{|c|c|c|}
\hline & Parameter Estimate & Marginal Impact \\
\hline Republican & $\begin{array}{l}.557 * * \\
(.240)\end{array}$ & $\begin{array}{c}+.22^{* *} \\
{[.039, .400]}\end{array}$ \\
\hline Independent & $\begin{array}{l}.568 * * \\
(.253)\end{array}$ & $\begin{array}{c}+.22 * * \\
{[.033, .414]}\end{array}$ \\
\hline Education & $\begin{array}{l}.226 * * \\
(.099)\end{array}$ & $\begin{array}{c}+.08 * * \\
{[.031, .145]}\end{array}$ \\
\hline Employed full time & $\begin{array}{l}.220 \\
(.201)\end{array}$ & $\begin{array}{c}+.08 \\
{[-.065, .230]}\end{array}$ \\
\hline Group 3 & $\begin{array}{c}1.996 * * \\
(.276)\end{array}$ & -- \\
\hline Group 4 & $\begin{array}{c}2.517 * * \\
(.271)\end{array}$ & -- \\
\hline Group 8 & $\begin{array}{c}1.460 * * \\
(.318)\end{array}$ & -- \\
\hline Constant & $\begin{array}{c}-2.996 * * \\
(.363)\end{array}$ & -- \\
\hline Wald Chisqr & $104.62 * *$ & \\
\hline Pseudo $\mathrm{R}^{2}$ & .41 & \\
\hline $\mathrm{N}$ & 356 & \\
\hline
\end{tabular}

Note: Figures in parentheses report robust standard errors. ${ }^{*} p<.10,{ }^{*} p<.05$, two-tailed test. Marginal Impacts report calculated as the change in predicted probabilities given a discrete change from 0 to 1 for dichotomous variables (Republican, Independent, Employed full time) and a +1 unit change for ordinal variables (Education) while holding all other variables to the following: Republican $=0$, Independent $=0$, Education $=2$ (high school diploma), Employed full time $=1$. Group 6 is the reference category. Figures in brackets report 95\% confidence intervals. 
Table 9. Which Party does Best Job of Making Economic Policy for the World Economy?

\begin{tabular}{lcccc}
\hline & $\begin{array}{c}\text { Democrats do } \\
\text { best job }\end{array}$ & $\begin{array}{c}\text { Republicans } \\
\text { do best job }\end{array}$ & $\begin{array}{c}\text { Both Parties } \\
\text { do good job }\end{array}$ & Totals \\
\hline $\begin{array}{l}\text { Non-Believers in Room to } \\
\text { Maneuver }\end{array}$ & $\begin{array}{c}18 \\
(27.7)\end{array}$ & $\begin{array}{c}26 \\
(18.0)\end{array}$ & $\begin{array}{c}35 \\
(33.3)\end{array}$ & 79 \\
Believers in Room to & 110 & 57 & 119 & 286 \\
Maneuver & $(100.3)$ & $(65.0)$ & $(120.7)$ & \\
Totals & 128 & 83 & 154 & 365 \\
\hline
\end{tabular}

Pearson chi2(2) test of hypothesis that rows and columns are independent $=9.03, p=0.01$.

Note: Cells report frequency of subjects in each category. Numbers in parentheses are expected frequencies.

Table 10. Satisfaction with Holding Elected Officials Accountable for Managing the Economy

\begin{tabular}{lccccc}
\hline & $\begin{array}{c}\text { Very } \\
\text { Satisfied }\end{array}$ & $\begin{array}{c}\text { Somewhat } \\
\text { Satisfied }\end{array}$ & $\begin{array}{c}\text { Not Too } \\
\text { Satisfied }\end{array}$ & $\begin{array}{c}\text { Not At } \\
\text { All } \\
\text { Satisfied }\end{array}$ & Totals \\
\hline $\begin{array}{l}\text { Non-Believers in } \\
\text { Room to Maneuver }\end{array}$ & 4 & 34 & 32 & 12 & 82 \\
Believers in Room to & 19 & $(32.8)$ & $(28.6)$ & $(15.6)$ & \\
Maneuver & $(18.0)$ & $(118.2)$ & $(103.4)$ & $(56.4)$ & 296 \\
Totals & 23 & 151 & 132 & 72 & 365 \\
\hline
\end{tabular}

Pearson chi2(3) test of hypothesis that rows and columns are independent $=1.89, p=0.60$. Note: Cells report frequency of subjects in each category. Numbers in parentheses are expected frequencies. 